\title{
Effect and Sustainability of Hybrid Training Styles on Speed, Accuracy, Knowledge Acquisition among Varying School Hockey Players
}

\author{
Sanmuga Nathan \\ Sultan Idris Education University of Malaysia
}

\begin{abstract}
The purpose of this study was to investigate the effects and sustainability of three hybrid training styles on school boys with, varying skill levels in field hockey. The three hybrid training styles incorporated three teaching styles from Mosston's Spectrum of Teaching Style and tactical model of TGfU: (a) Style B Tactical (SBT), (b) Style E Tactical (SET), and (c) Style H Tactical (SHT). Students in Physical Education classes with $n=225$ boys were selected via stratified random sampling technique. Findings indicate that three hybrid training styles were effective in the speed and accuracy of executing general hockey skills, learning declarative and procedural knowledge. Findings also indicate that only the SHT hybrid model sustained its performance across the three posttests on procedural knowledge. Results also indicated that High skilled students (HS) showed significant improvement in speed and accuracy while executing general hockey skills. The findings illustrate that these hybrid styles appear to be suitable for a long-term training program.
\end{abstract}

Keywords: Style B tactical, style E tactical, style H tactical, speed and accuracy, declarative and procedural knowledge

\section{Introduction}

Games are important components in the physical education curriculum worldwide and it is imperative that students with varying skill level be given the opportunity to participate and upgrade their games performance (Holt, Strean \& Bengoecha, 2002; Rovegno, Nevett \& Babiarz, 2001). To achieve this teachers have available to them various teaching styles (Mosston \& Ashworth, 2002) and models like the Teaching Games for Understanding (TGfU) (Bunker \& Thorpe,1982).

Teachers can also use teaching styles and curriculum models in combination to improve learning outcome various abilities students in Physical Education noted by (Capel, 2005) but in order to advance PE pedagogy this combination can be try out in improving games performance too. A teacher could use teaching styles such as Practice (Style B), Inclusion (Style E) and Divergent Discovery (Style $\mathrm{H}$ ) from the Spectrum of Teaching Styles (Mosston \& Ashworth, 2002) and incorporate them with TGfU to form an effective games hybrid game training styles which may prove to be more interesting for learners. Findings from various research indicates that interesting physical education lessons lead to improvement in game play as well as an improved fitness level (Corbin, 2002; Dodds, Griffin \& Placek, 2001; Holt et al., 2002; Oslin, Mitchell \& Griffin, 1998).
Ishee (2004) noted that young students will continue to play games if they are capable of performing the activity. Students of different skill level, as well as the late and early bloomers require different methods of teaching and training for games to suit them. This is because the highly-skilled students have superior neuromuscular abilities; eye-leg coordination and high cognition readiness and therefore, they are able to sustain the high level and complex's training regimes compared to low skill and late bloomers (Wrisberg, 1993). High skilled and low skilled players need different types of teaching approaches to optimize their game performance. These can be done by producing research based games teaching and curriculum to upgrade games performance (Rink, French \& Graham, 1996; Rink, 2002). It is important that different ability students get the right training tasks. as well as to motivate them to play games. Students more likely to be motivated and interested in games lessons that emphasize game plays (Dodds et al., 2001). Players in the developmental age group of 12-13 year-old are suitable to use game play as form of multilateral teaching activity to enhance basic fitness, motivation and cooperation (Bompa, 1999).

Games training should be geared towards manipulation of tactics, skills, speed, coordination, flexibilities, aerobic, anaerobic, as well as speed and accuracy (Drewe, 2000; Wassmer \& Mookerjee, 2002; Wilsmore \& Curtis, 1992). In an invasion game like hockey, players need to have a good command of game 
knowledge for quick decision-making as to "what to do" and "how to do" tactics, speed and accuracy in executing skills at the right time in a game play (Germaine, Godbout \& Bouthier, 2001; Light, 2005; Siedentop, 2001).

\section{Theoretical Framework}

The sports and physical education field provide theory and models in teaching and coaching to upgrade games performances. The Spectrum of Teaching Styles (Mosston \& Ashworth, 2002) and the tactical TGfU model proposed by Bunker and Thorpe (1982) have variables to upgrade games performance (Mandigo \& Holt, 2002; Turner \& Martinek, 1999). Styles of teaching and a tactical model will benefit students at various skill levels (Philip dan Wikersoon, 1990). Physical educators around the world have embraced the Spectrum of Teaching Styles as a framework for delivering instruction in schools (Byra, 2000). The Spectrum of Teaching Styles is divided into reproductive and productive. The reproductive cluster is teachercentered, and, includes the command (A), practice (B), reciprocal (C), self-check (D) and inclusion (E) teaching styles. The productive cluster is learner-centered and includes guided discovery (F), convergent discovery (G), divergent production $(\mathrm{H})$, individual models learner design (I), learner-initiated $(\mathrm{J})$, and selfteaching $(\mathrm{K})$.

TGfU, was suggested as a better model of teaching games compared to a technical model (Hopper, 2002). The technical model lessons are considered too structured, with warming up activities and skill drills as the main components and students lack of chances to play in game play. The emphasis of this technical model is on acquiring technical skills for game play, while the cognitive skills essential for effective participation in games are often undermined (Turner \& Martinek, 1999). As a result, it is suggested that students fail to transfer the skill and knowledge, tactical decision making elements of game performance to game plays. Proponents of the TGfU model suggest that exposing students to game like experiences early in the teaching-learning process helps them acquire substantive declarative and procedural knowledge, thereby facilitating tactical decision making during game play (Crespo, Reid \& Mileyo, 2004; Grehaigne \& Godbout, 1995; Mitchell, Griffin \& Oslin, 1994; Turner, 1996; Turner \& Martinek, 1999; Werner, Thorpe \& Bunker, 1996).

Research on the Spectrum of Teaching Styles has mainly employed the technical model of teaching. Whereby in technical model, lessons are arranged in a structural sequence with warming up activities, followed skill driven lesson and mini game and limbering down activities (Turner \& Martinek, 1999). Findings shows that there were significant improvements in skill performance in sports and games (Harrison et al., 1995; Boyce, 1992; Goldberger \& Gurney 1986). In comparison, there is no research that incorporates Style B, E and $\mathrm{H}$ respectively with TGfU. Even though TGfU may be effective in a game decision making, upgrading declarative and procedural game knowledge there is not much evidence to show TGfU is efficient at improving skill execution in the game play (Holt et al., 2002). Hopper (2002) and Rink (2002) suggested that TGfU could be combined with a technical model to form an effective game teaching approach and hat researcher should not waste time measuring skill versus tactic approach as best method of teaching games. A number of research studies using Styles B, E and H of the Spectrum of Teaching styles incorporated a technical model in sports like shooting, karate, hockey, volleyball (Boyce, 1992; Goldberger \& Gurney 1986; Harrison et al., 1995; Goldberger \& Howarth, 1993). However, games like hockey, volleyball and racquetball need tactical as well as skill components to upgrade games performance. Therefore, the tactical model of training or teaching equally important as technical model.

Research on using the TGfU model showed that this model was effective in hockey (Turner, 1996; Turner \& Martinek, 1999), tennis (Crespo et al., 2000), basketball and hockey (Light \& Fawns, 2003), basketball (Nevett et al., 2001), especially in game components like ball control, decision making on tactical elements of the games, as well as in upgrading declarative and procedural knowledge (French et al., 1996; Tuner \& Martinek, 1996). However, the handicap part of the TGfU model many be in the execution of skill (dribbling, goal scoring, tackling) in hockey game play. Therefore, by incorporating the Spectrum of Teaching Styles style B, E and H respectively with the TGfU model the possibility for the students at various skill levels would enhance their game performance.

The purpose of this study was to investigate the effectiveness and sustainability of three hockey hybrid training styles on boys with different skills levels. The three hybrid training styles combine three different teaching styles with the TGfU (tactical) model were labelled as Style B tactical (SBT), Style E tactical (SET) and Style H tactical (SHT). The training models were formed using style B: practice, style E: inclusion and style $\mathrm{H}$ : divergent discovery proposed in the Spectrum of Mosston dan Ashworth Teaching Styles. These selected styles were incorporated with the TGfU model. The effectiveness and sustainability of the three hockey hybrid training 
styles were evaluated by measuring the speed and accuracy of executing general hockey skills, students' acquisition of declarative and procedural hockey knowledge. Furthermore, measure of ball control, decision making (dribbling, tackling, passing and scoring) and skill execution (dribbling, tackling, passing and scoring) in game play were considered, which were recommended by Tuner and Martinek (1999).

\section{Research questions}

The purpose of the study was to investigate the effectiveness and sustainability of three hybrid training styles among varying skilled school boys. The study, in particular, aimed to address the following research questions:

1. Are the SBT, SET and SHT hybrid training styles effective in increasing the speed and accuracy during the execution of general hockey skills?

2. Do students classified as high (HS), medium (MS), and low (LS) skilled perform better in executing general hockey skills of speed and accuracy using SBT, SET and SHT hybrid training styles?

3. Are the SBT, SET and SHT hybrid training styles effective in helping students sustain their performance in the speed and accuracy during the execution of general hockey skills?

4. Are the SBT, SET and SHT hybrid training styles effective in students' acquisition of declarative, procedural knowledge acquisition?

5. Do HS, MS, and LS students perform better in the acquisition of declarative and procedural knowledge using SBT, SET and SHT hybrid training styles?

6. Are the SBT, SET and SHT hybrid training styles effective in helping students

\section{Methodology}

A quasi experimental balanced factorial design with Repeated Measures was employed using pretest score of dependent variables as covariate. The three hybrid training styles served as independent variables. The dependent variables consist of speed and accuracy executing general hockey skills, multiple choice written test of declarative and procedural knowledge. The study was carried out over a period of 15 weeks during Physical and Health Education classes. The study involved 225 school boys aged 12-13 years who were divided equally into three training models; SBT, SET and SHT which comprised HS MS and LS. The skill groups were divided based on the speed and accuracy at executing general hockey skills. The training intervention used 12 lessons in six weeks of physical education classes. The pretest was conducted at the first week before training intervention. Posttest I was conducted at the eight week mark, immediately after training intervention to determine the training effects. Posttests II and III were again conducted to collect data at the $12^{\text {th }}$ week and $15^{\text {th }}$ week respectively, to access the sustainability or retention of these three hybrid training styles without training intervention.

\section{Intervention}

The B, E and $\mathrm{H}$ styles used different approaches in carrying out the daily training unit. The selected styles divided into three section, the pre impact set (before lesson), impact set (during lesson) and post impact set (at the end of lesson). Style B is a teacher centered style, whereas Style E the teacher arranged training tasks at different difficulties levels and students choose lesson according to their abilities. Style $\mathrm{H}$ was student centered and they make the decision to solve the tactical problem. The content of SBT, SET and SHT training based on scoring strategy, preventing scoring strategy and restarting play strategy using mini game with tactical approach of TGfU. Furthermore, six steps in teaching TGfU were used, (1) game form, (2) game appreciation, (3) tactical awareness, (4) making appropriate decisions, (5) skill execution and finally, (6) performance is based the whole process (Griffin \& Patton, 2005; Mitchell et al., 1994). The training models used mini game play and skill drills as main activities to improve students tactical strategy, conditioning, techniques components on line multilateral training principle for young players. The training models were prepared on simple periodization and motor learning theory (Bompa, 1999; Fitts \& Posner, 1967). Refer Figure 1 for hybrid training modules which were built using teaching styles $\mathrm{B}, \mathrm{E}$ and $\mathrm{H}$ incorporate with tactical model of TGfU respectively and Table 1 , shows training blocks of the three hybrid training styles according weekly micro cycles 


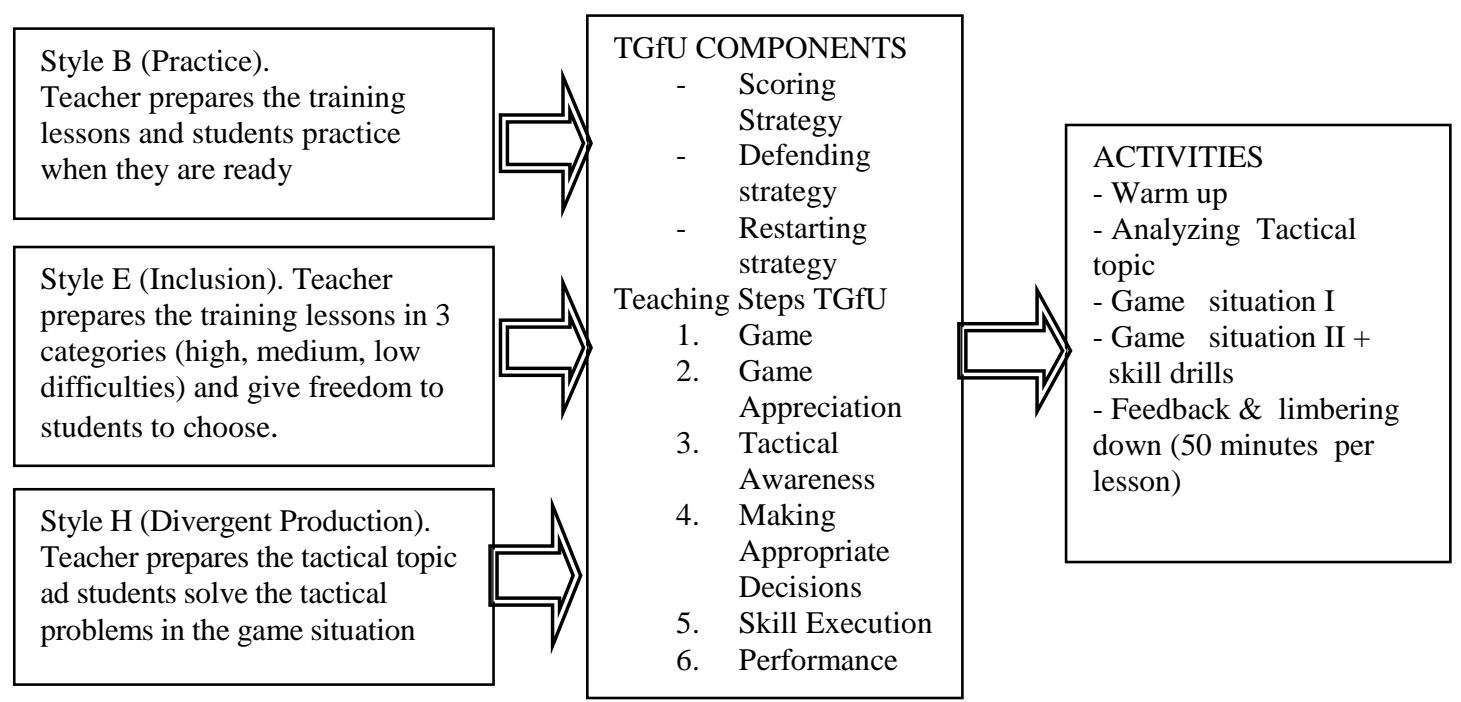

Figure 1. Hybrid training styles based on styles and TGfU

Table 1. Tactical approach of field hockey hybrid training styles.

\begin{tabular}{|c|c|c|c|}
\hline Wks & Tactical Problems & Training Objectives & $\begin{array}{l}\text { a. Intensity } \\
\text { b. volume }\end{array}$ \\
\hline 2 & \multirow{7}{*}{$\begin{array}{l}\text { Scoring } \\
\text { - Maintaining } \\
\text { possession } \\
\text { of the ball } \\
\text { - Attacking } \\
\text { the goal } \\
\text { - Creating } \\
\text { space in } \\
\text { attack }\end{array}$} & Tactics & \multirow{7}{*}{$\begin{array}{l}\text { Week 1, 2, } 3 \\
\text { a. } 55-70 \% \\
\text { b. } 70-90 \% \text { Week 3, } 4 \\
\text { a. increase to } 85 \% \\
\text { b. reduce to } 65 \% \\
\text { Week } 5,6 \\
\text { a. increase to } 70 \% \\
\text { b. reduce to } 55 \%\end{array}$} \\
\hline 3 & & $\begin{array}{l}\text { - so that players able to posses, maintain the ball, create, } \\
\text { use space while attacking }\end{array}$ & \\
\hline & & - so that players able to control, the ball passing, & \\
\hline 4 & & $\begin{array}{l}\text { dribbling, anticipating, tackling and scoring goal skills. } \\
\text { - players without ball able to provide width and support to }\end{array}$ & \\
\hline 5 & & & \\
\hline 6 & & $\begin{array}{l}\text { declarative and procedurals game knowledge. } \\
\text { Conditioning }\end{array}$ & \\
\hline 7 & & $\begin{array}{l}\text { - so that the players buildup aerobic endurance, strength, } \\
\text { agility using mini game situation } \\
\text { Techniques } \\
\text { - Skill drills in game plays }\end{array}$ & \\
\hline 2 & \multirow{6}{*}{$\begin{array}{l}\text { Prevention of } \\
\text { Scoring } \\
\text { - Defending } \\
\text { space } \\
\text { - Defending } \\
\text { the goal } \\
\text { - Winning the } \\
\text { ball }\end{array}$} & Tactics & \multirow{6}{*}{$\begin{array}{l}\text { Week 1, 2, } 3 \\
\text { a. } 55-70 \% \\
\text { b. } 70-90 \% \\
\text { Week 3, } 4 \\
\text { a. increase to } 85 \% \\
\text { b. reduce to } 65 \% \\
\text { Week 5, } 6 \\
\text { a. increase to } 70 \% \\
\text { b. reduce to } 55 \%\end{array}$} \\
\hline 3 & & $\begin{array}{l}\text { - so that players will defense the space and goal mouth } \\
\text { from attacking by opposite team. }\end{array}$ & \\
\hline 4 & & $\begin{array}{l}\text { - so that players able to use skill such as ball control, } \\
\text { passing, dribbling, anticipating, tackling in defending. }\end{array}$ & \\
\hline 5 & & $\begin{array}{l}\text { - so that players will repossesses the ball from attacking } \\
\text { players }\end{array}$ & \\
\hline 6 & & Conditioning & \\
\hline 7 & & $\begin{array}{l}\text { - so that the players buildup aerobic endurance, strength, } \\
\text { agility using mini game situation } \\
\text { Techniques } \\
\text { - Skill drills in game plays }\end{array}$ & \\
\hline 2 & \multirow{6}{*}{$\begin{array}{l}\text { Restarting Play } \\
\text { - Push in } \\
\text { - Hit in }\end{array}$} & Tactics & \multirow{6}{*}{$\begin{array}{l}\text { Week } 1,2,3 \\
\text { a. } 55-70 \% \\
\text { b. } 70-90 \% \\
\text { Week 3, } 4 \\
\text { a. increase to } 85 \% \\
\text { b. reduce to } 65 \% \\
\text { Week } 5,6 \\
\text { a. increase to } 70 \% \\
\text { b. reduce to } 55 \%\end{array}$} \\
\hline 3 & & $\begin{array}{l}\text { - so that the players will employ right } \\
\text { push or hit tactics accurately in penalty }\end{array}$ & \\
\hline 4 & & $\begin{array}{l}\text { corner, long corner execution and also } \\
\text { during the restarting of the game }\end{array}$ & \\
\hline 5 & & Conditioning & \\
\hline 6 & & $\begin{array}{l}\text { - so that the players buildup aerobic } \\
\text { endurance, strength, agility using mini } \\
\text { game situation }\end{array}$ & \\
\hline 7 & & $\begin{array}{l}\text { Techniques } \\
\text { - Skill drills in game plays }\end{array}$ & \\
\hline
\end{tabular}


In SBT hybrid training model, the teacher prepares the training model at pre impact set, and during impact set (during lessons), the teacher guides and implement this training model, groups will be using task cards and during post impact set the teacher gives feedback and discuss about the lesson. With the SET model, at impact set the teacher prepares the lesson based on different difficulty levels to cater for students with high skill level, medium skill level and low skill level by adjusting (i). Size of hockey field size, (ii). Number of players, (iii). Time allocation for each game play, (iv). Size of hockey goal mouth, (v). Guarding goal post with hockey keeper and without keeper. At impact set the students in groups, select the entry level and proceed with activities using task cards and at post impact set the teacher gives feedback and discuss about the lesson As for SHT model, the teacher prepares the tactical problem questions with task cards for the groups, so that students will solve the tactical problem in the game play during impact set. At the post impact set, as usual there will be a feedback and discussion session. Basically, the three hybrid training styles comprise the same stages of activities, but the training styles of each training model were different and 40 minutes were given for each lesson.

Stage 1 - Warming up activities (mini hockey games with stretching exercises) activities in groups.

Stage 2 - Analyzing tactical activities. In this stage students analyses the tactical topic which they going to do. This activity is to increase game appreciation, tactical awareness, making appropriate tactical decision, executes the right skill in game play.

Stage 3 - Activities in game play I (refer the tactical topic from Table.1) Teacher observe and interfere when necessary.

Stage 4 - Activities in game play II (same topic with situation I plus skill drill activities).

Stage 5 - Limbering down activities and game feedback session.

The three hybrid training styles were conducted by three qualified physical education teacher who taught more than 10 years. In order to maintain the fidelity in implementation of these three hybrid training styles the following steps were taken. A simultaneous briefing session was conducted on how to implement these three different hybrid training styles, by the principal researcher. The three teachers were given modules and checklist on implementing these three styles. A pre training stint was conducted by researcher on implementation of these three training intervention and method on carrying out all the required test of measures. A pre interviews was conducted by the principal researcher to make sure these teachers conducted the training units accordingly

\section{Instrumentation}

The Henry Freidel Field Hockey Test (H.F.F.H.T) adapted from Turner and Martinek (1999) was used to measure general field hockey tests in speed and accuracy of executing hockey skill. This test incorporated the skills of ball control, dribbling, tackling, evading an opponent and shooting. The reliability using H.F.E.H.T in Malaysian environment was calculated using Cronbach's alpha at .81 for speed of execution and .72 for accuracy of executing skill using pilot test results.

The Hockey Knowledge multiple choice test was used to measure students' declarative and procedural knowledge. Used by by Messick (1987), it has 15 declarative and 15 procedural knowledge items testing students' hockey knowledge. These questions were piloted among Malaysian school students (12-13 year-old) and the reliability was calculated using Cronbach's alpha at .52 for 15 declarative questions and .54 for another 15 procedurals knowledge.

\section{Data Analysis}

The dependent groups for general hockey skill variables for speed score represented in time and accuracy was a total score out of nine marks. The dependent group of knowledge variables, declarative and procedural knowledge were based on a total score on the 30 multiple questions. The effect of the SBT, SET and SHT hybrid training styles according skills level (HS, MS and LS) in speed and accuracy executing general skill, declarative and procedural knowledge at posttest I were analyzed using Multivariate test of MANCOVA and followed by ANCOVA test if the MANCOVA yield significant result. Pair wise comparison and mean score were used to determine the most effective training model. Pretest score on speed and accuracy executing general skill, declarative and procedural knowledge was used as covariates. The boys were tested again across three posttests to determine the sustainability or retention of these training models. The results were analyzed using Two-Way ANOVA of Repeated Measures and the mean score across the three posttests were used to determine the sustainability of the training models.

\section{Results}

A MANCOVA showed that SBT, SET and SHT hybrid training styles performed significantly better in speed and accuracy executing general hockey skills at posttest I, (Wilks' A $=.888, F(4,426)=$ 6.49, $p<.05)$. An ANCOVA for speed variable indicated a significant main effect of the three 
training models, $F(2,214)=3.42, p<.05$, at posttest I, for accuracy variable indicated a significant main effect of the training models at posttest I, $F(2,214)=9.61, p<.05$. A pair wise comparison indicated that SET was the best hybrid training model for speed and accuracy executing general hockey skill posttest I. The test also indicated there was a significant main effects among skills group in speed and accuracy executing hockey skills at posttest I (Wilks' A = $.955, F(4,426)=2.46, \quad p<.05)$. An ANCOVA results for speed variable indicated a significant main effect of the training models among skills group at posttest I, $F(2,215)=3.871, p<.05$, and for accuracy there was no main effect of the training models among skills group, $F(2,215)=$ $1.33, p>.05$. Based on mean score HS group outshined the other skills group in speed and accuracy of executing hockey skill at posttest I.

ANOVA two-ways of repeated measures for sustainability of the training models on speed across three posttests indicated significant changes in mean score performance $F(2,221)=45.98$, p < 0.05 ( Huynh-Feldt within subject test also indicated significant result, $D F(2,148) p=0.01)$. Based on mean score SET hybrid training model managed to sustain only from posttests I to II, refer table 2. As for accuracy, the three hybrid training styles also indicated significant changes in means score performance across three posttests, $F(2,221)$ $=2.65, p<0.05$ (Huynh-Feldt test also indicated significant result $D F(2,148) \quad p=.031)$. For accuracy based on mean score SHT training sustain from posttests I-II, refer table 2 for speed and accuracy.

Table 2. Means, SD and three posttest results for speed and accuracy executing hockey skills.

\begin{tabular}{llll}
\hline $\begin{array}{l}\text { Executing Skills } \\
\text { Models }\end{array}$ & $\begin{array}{l}\text { Posttest I } \\
\text { Mean (SD) }\end{array}$ & $\begin{array}{l}\text { Posttest II } \\
\text { Mean (SD) }\end{array}$ & $\begin{array}{l}\text { Posttest III } \\
\text { Mean (SD) }\end{array}$ \\
\hline Speed & & & \\
SBT & $25.49(3.60)$ & $26.77(3.87)$ & $28.04(4.65)$ \\
SET & $26.33(4.11)$ & $26.25(4.16)$ & $27.05(5.02)$ \\
SHT & $25.3(3.18)$ & $25.75(3.36)$ & $27.16(4.75)$ \\
Accuracy & & & \\
SBT & $7.56(1.34)$ & $7.16(1.39)$ & $6.79(1.72)$ \\
SET & $7.53(1.29)$ & $7.43(1.37)$ & $6.87(1.48)$ \\
SHT & $6.68(1.43)$ & $7.24(1.51)$ & $6.81(1.62)$ \\
\hline
\end{tabular}

\section{Analysis of Declarative and Procedural knowledge}

The SBT, SET and SHT training styles performed significantly better in declarative and procedural hockey knowledge at posttest I based on MANCOVA result, Wilks' $\mathrm{A}=.920, F(4,426)=$ 4.54, $p<0.05$. An ANCOVA for declarative knowledge indicated a significant main effect of the three hybrid training styles at posttest I, $F(2$, $214)=6.729, p<0.05$, and for procedural indicated there was no significant main effect of the three training at posttest I, $F(2,214)=1.568, p>0.05$. Based on pair wise comparison and mean score indicated that SHT models was the best training model for declarative and SBT $\mathrm{t}$ for procedural. There was no significant main effect of the training models among skill groups (HS, MS, LS) in declarative and procedural at posttest I, Wilks' A = $.984, F(4,426)=.84, p>0.05$.

ANOVA two-ways of repeated measure test for sustainability of the three hybrid training styles on declarative knowledge across three posttests indicated significant changes in mean score performance $F(2,221)=8.03, p<0.05$, (HuynhFeldt test also indicated significant result $D F(2,148), p<0.05)$. Based on mean score the SBT and SHT training especially at posttest III showed some sustainability in declarative knowledge (refer table 3 and figure 2).

Table 3. Means, SD and posttests results for declarative and procedural hockey knowledge.

\begin{tabular}{llcl}
\hline $\begin{array}{l}\text { Knowledge } \\
\text { Models }\end{array}$ & $\begin{array}{l}\text { Posttest I } \\
\text { Mean (SD) }\end{array}$ & $\begin{array}{l}\text { Posttest II } \\
\text { Mean (SD) }\end{array}$ & $\begin{array}{l}\text { Posttest III } \\
\text { Mean(SD) }\end{array}$ \\
\hline Declarative & & & \\
SBT & $7.16(2.57)$ & $7.24(2.84)$ & $8.15(2.65)$ \\
SET & $8.40(3.184)$ & $7.37(3.39)$ & $7.57(2.67)$ \\
SHT & $9.06(2.57)$ & $9.04(2.99)$ & $9.92(3.19)$ \\
Procedural & & & \\
SBT & $7.24(2.99)$ & $6.45(2.63)$ & $6.92(2.68)$ \\
SET & $6.48(2.54)$ & $6.31(2.75)$ & $6.26(2.49)$ \\
SHT & $7.07(3.081)$ & $7.11(2.72)$ & $7.59(3.23)$ \\
\hline
\end{tabular}




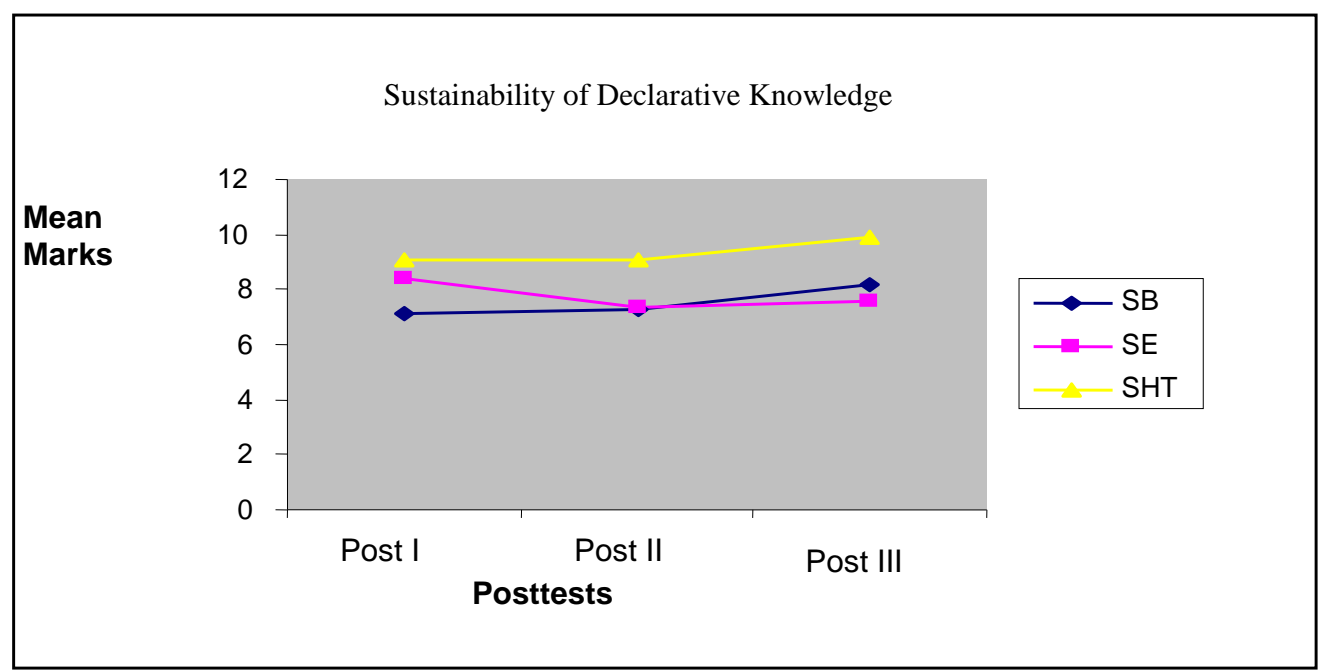

Figure 2. Sustainability of declarative knowledge.

As for procedural knowledge, there was no significant changes in mean score among boys across three posttests, $F(2,221), p>0.05$, (HuynhFeldt test also indicated no significant result $D F(2,148), p>0.05)$, Based on mean score the SHT training styles showed sustainability in performance across three posttests compared to the other training in procedural knowledge (refer table 3 and figure 3 ).

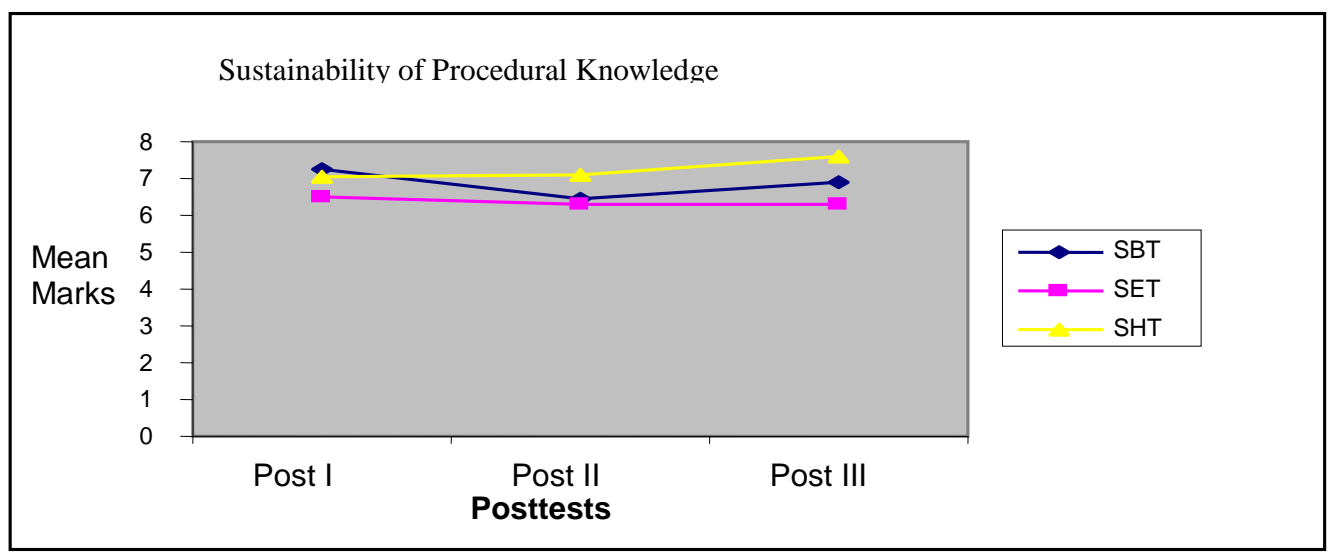

Figure 3. Sustainability of procedural knowledge.

\section{Discussion}

\section{Speed and Accuracy Executing Hockey Skills}

There was significant improvement in speed and accuracy in executing hockey general skill among boys using the three training styles at posttest I. This finding supports the importance of mini game activity via TGfU to enhance speed and accuracy executing hockey skills. As speed and accuracy proven to be an important element in scoring goal in hockey game (Aziz, Chia \& Teh, 2000; Wassmer \& Mookerjee, 2002). The SBT, SET and SHT training models which largely emphasizes the mini games activities. These mini games activities which were periodized based on volume and intensity that had also improved speed and accuracy executing skills and in line with the training principle (Thompson, 2000; Shepherd, 2007). Furthermore the hybrid training styles which combined Styles B, E and $\mathrm{H}$ of the Spectrum Teaching Styles with TGfU model. The combination theory and model had upgraded the boys' performance. The SET training was the most efficient training style at posttest I due to the contents of Style E (Inclusion style) teaching, which benefited students from varying skill level.

This effectiveness of style $\mathrm{E}$ in speed and accuracy of executing skills were parallel to the findings of style B (Harrison et al., 1995) and Boyce (1992). The findings of style E showed that the boys in various skill groups benefited from the 
training programme by improving in speed and accuracy of executing skills when compared to the earlier finding of style $E$ by Goldberger and Gurney (1986), which only benefited the low skill boys. These findings also showed that HSB achieved significantly better than MSB and LSB in speed and accuracy using SBT, SET and SHT at posttest I. These findings parallel with the motor learning principle that high skill players have better neuromuscular, eye-leg coordination, fast reflexes, motivation and high concentration (Harrison, 1983; Wrisberg, 1993). The achievement of HSB in speed and accuracy in this research was parallel with previous research (Gemser et al., 2004; Hebert, Landin \& Solmon, 1996; Nevett et al., 2001). These findings however, somewhat contradict earlier findings that low skill players are better than high skill students in ball spiking skills in volleyball (Harrison et al., 1995).

As for sustainability in speed of executing general hockey skills, the three training styles couldn't sustain its performance across three posttests. SET training model was the best programme compared to other models based on mean score in speed. As for accuracy in executing hockey skill, based on mean score the SHT training models showed some form of sustainability from posttest I-II. This was due to the role of style $\mathrm{H}$ with the TGfU model generated how to decide on how and when to execute the skill with accuracy and timing. This research gives a new dimension on TGfU. Previous study by Turner dan Martinek (1999) in hockey and French et al.( 1996) in badminton ignore the element of sustainabiliy in teaching and training styles. Incooperating styles of teaching with TGfU could be the catalyst for enhancing performance, but nevertheless, continuous training must be given priority in upgrading games performances as part of a long term training schedule.

\section{Declarative and Procedural Hockey Knowledge}

The SHT style showed significant improvements in players' declarative knowledge at posttest I. The main reason could be the usage of style $\mathrm{B}, \mathrm{E}, \mathrm{H}$, especially $\mathrm{H}$ Style with the tactical model TGfU. Furthermore, the boys understood the game form and rules of the game as suggested by TGfU model. These findings in declarative knowledge were parallel with previous findings of Denis (1993), Dodd (et al., 2001) and Tuner (1996). In particular, Style H incorporated with TGfU led to improvements in the boys' performance. Student centered learning, such as Style $\mathrm{H}$ and TGfU, are inclined to constructivism theory of teaching (Metzler, 2005). But in contrast, the boys did not improve significantly in procedural knowledge at posttest I, probably due to lack of understanding "how to do it" (as suggested in teaching steps of
TGfU). This finding of procedural knowledge parallels with the findings of Harrison et al. (2004) and Turner (1996). Results also showed that there were no differences among skills group in declarative and procedural hockey knowledge at posttest I. This implies that the skills group practice did not play important role in declarative and procedural hockey knowledge acquisition. These findings contradict previous research that there will be significant better performance achieved by low skills group compared by other groups, (Harrison et al., 2004).

The SHT hybrid training styles recorded sustainable performance in declarative and procedural knowledge among boys throughout the three posttests compared to the other models. The SHT hybrid training model was able to sustain its performance across the three posttests. This was because the hybrid training styles which has the combination of Style $\mathrm{H}$ and TGfU model. The importance of acquisition of declarative and procedural as a prerequisite for tactical and skill decision making in game play (Grehaigne \& Godbout, 1995).

\section{Conclusions}

The results from the present study suggest that hybrid training styles can be utilized in physical education classes to upgrade games performance. Fun mini games situations using a variety of teaching styles incorporated with the TGfU model have the potential to upgrade players' game performance. Teachers and coaches can utilize SET hybrid training styles as a short term and long term training programme to upgrade boys' performance of speed in executing skill as well as decision making in game play. The SHT hybrid training styles can be used as a long term training programme to upgrade accuracy in executing hockey skill, declarative and procedural knowledge. Additionally, SHT training styles can be used as a short term training programme for ball control in game plays. The SBT hybrid training model is suitable as a short term training programme for skill execution in game plays and as a long term programme to enhance declarative knowledge. This research had utilized three teaching styles (B, E, and $\mathrm{H}$ ) from The Spectrum of Teaching Styles. Future research should incorporate other teaching styles with the TGfU model and use other age groups samples. This research used the Henry Freidel Field Hockey test to select the skill samples based on speed and accuracy in executing hockey general skills. Future studies could use an agility test like the Chapman Ball Control test (Johnson \& Nelson, 1986). Agility test are suitable to hockey players as they change their direction while playing in the game play. 


\section{References}

Anders, E., \& Myers, S. (1998). Field hockey: Steps to success. Champaign, IL: Human Kinetics.

Anderson, J. R. (1976). Language memory and thought. Hillsdale, NJ: Erlbaum.

Aziz, A. R., Chia, M., \& Teh, K. C. (2000). The relationship between maximal oxygen uptake and repeated sprint performance indices in field hockey and soccer players. Journal Sports Medicine and Physical Fitness, 40, 195-200.

Bompa, T. (1999). Periodization: Theory and methodology of training. Champaign, IL: Human Kinetics.

Boyce, B. A. (1992). The effects of three styles of teaching on university students' motor performance. Journal of Teaching Physical Education, 18, 389-401.

Bunker, D., \& Thorpe, R. (1982). A model for the teaching of games in the secondary schools. The Bulletin of Physical Education, 10 , 9-16.

Byra, M. (200). A Review of Spectrum Research: The Contributions of Two Eras. Quest., 52, 229-245.

Capel, S. (2005). Teaching, Teaching and Pedagogy in Physical Education. Physical Education Essential. London: Sage

Crespo, M., Reid, M. M., \& Miley, D. (2004). Tennis: Applied examples of a game-based teaching approach. Strategies, 17(4), 27-31.

Corbin, C.B. (2002). Physical activity for everyone: What every physical educator know about promoting lifelong physical activity. Journal of Teaching Physical Education, 21, 128144.

Denis, G. (1993). Human Skills: Ideas, Concepts and Models. Handbook Research in Sports Psychology. New York. Macmillan Publishing Company.

Dodds, P., Griffin, L. L., \& Placek, J.H. (2001). Selected review of the literature on development of learners" domainspecific knowledge. Journal of Teaching Physical Education, 20, 301-313.

Drewe, S. B. (2000).An Examination of the Relationship Between Coaching and Teaching. Quest., 52, 79-88.

Fitts, P.M., \& Posner, M.I. (1967). Human Performance. Belmont, CA:Brooks and Cole Publishing.

French, K. E., Werner, P. H., Taylor, K., Hussey, K., \& Jones, J (1996). The effects of a 6 week unit of tactical, skill, or combined tactical and skill instruction on badminton performance of ninth-grade students. Journal of Teaching Physical Education, 15, 439-463.

Gemser, M. T., Visscher, C., Lemmink, K., \& Mulder,T. W. (2004). Relation between multidimensional performance characteristics and level of performance in talented youth field hockey players. Journal of Sports Sciences, 22(1112), 1053-1063. Grehaigne, J. F., \& Godbout, P. (1995). Tactical knowledge in team sports from a constructivist and cognitivist perspective. Quest, 47, 490-505

Grehaigne, J. F., Godbout, P., \& Bouthier, P. (2001). The teaching and learning of decision making in team sports. Quest, 53, 59-75.

Goldberger, M., \& Gerney. (1986) Teaching strategies and instructional formats in physical education: Total teaching or ideology. The British Journal of Physical Education, 24(1), 5-9.

Goldberger, M., \& Howarth, K. (1993). The national curriculum in physical education and the spectrum of teaching styles. The British Journal of Physical Education, 24(1), 23-26.

Griffin, L. L., \& Patton, K. (2005). Two decades of teaching games for understanding: Looking at the past, present and future in Griffin, L.L., \& Butler, J.I. (2005). Teaching games for understanding: Theory, Research, and Practice. Champaign, IL: Human Kinetics.

Harrison, J.M. (1983). Instructional strategies for physical education. Dubuque, IA: Wm. C. Brown Company.

Harrison, J. M., Blakemore, C. L., Richards, R. P., \& Oliver, J. (2004). The effects of two instructional models-tactical and skill teaching on skill development and game play, knowledge, self - efficacy, and student perceptions in volleyball. Physical Educator, 61(4), 186-200.
Harison, J. M., Fellingham, G. W., Buck, M. M., \& Pellet, T.L. (1995). Effects of practice and command styles on rate of change in volleyball performance and self - efficacy of high, medium, and low skilled learners. Journal of Teaching Physical Education, 14, 328-339.

Harvey, S. (2003). A study of U19 college soccer players improved in game performance using the game performance assessment instrument. Proceedings of the $2^{\text {nd }}$ international conference on teaching sport and physical education for understanding. University of Melbourne, Australia.

Hebert, E. P., Landin, D., \& Solmon, M. A (1996). Practice schedule effects on the performance and learning of low and high skilled students: An applied study. Research Quarterly for Exercise and Sport, 67, 52-58.

Holt, N. L., Strean, W. B., \& Bengoechea, E. G. (2002). Expanding the teaching games for understanding model: New avenues for future research and practice. Journal of Teaching Physical Education, 21, 162-176.

Hopper, T. (2002). Teaching games for understanding: The importance of student emphasis over content emphasis. Journal of Health, Physical Education, Recreation \& Dance, 73(7), 44-48.

Ishee, J. H. (2004). Are physical education classes encouraging students to be physically active. Journal of Physical Education, Recreation \& Dance, 75(2), 1-2.

Johnson, B. L., \& Nelson, J.K. (1986). Practical measurements for physical education. $\left(4^{\text {th }}\right.$ Ed). New York: Macmillan.

Light, R. (2003). The joy of learning: Emotion and learning in games through TGfU. Journal of Physical Education New Zealand, 36(1), 93-103.

Light, R. (2005). Making sense of chaos: Australian coaches talk about game sense, In LL Griffin and JL Butter (eds) Teaching games for understanding: Theory, research and practice. Champaign, IL: Human Kinetics.

Light, R. \& Fawns, R. (2003). Knowing the game: Integrating speech and action in games teaching through TGfU. QUEST. National Association for Kinesiology and Physical Education in Higher Education, 55, 161-176.

Mandigo, J. L., \& Holt, N. L. (2002). The inclusion of optimal challenge in teaching games for understanding. Brock University, Department of Physical Education:1-23

Messick, J. N. (1987) dalam McGhee, R., \& Barrow, A. (1987). Field hockey: Questions for physical education activities test Champaign, IL: Human Kinetics.

Metzler, M. (2005). Implications of models-based instruction for research on teaching: A focus on teaching games for understanding dalam Griffin, L.L., \& Butler. J.I . (2005). Teaching games for understanding: Theory, Research, and Practice, Champaign, IL: Human Kinetics.

Mitchell, S. A., Griffin, L. L., \& Oslin, J. L. (1994). Tactical awareness as a developmentally appropriate focus for teaching of games in elementary and secondary physical education. The Physical Educator, 51, 21-27.

Mosston, M., \& Ashworth, S. (2002). Teaching physical education. $\left(5^{\text {th }} \mathrm{Ed}\right)$. New York: Benjamin Cummings.

Nevett, M., Rovegno, I., Babiarz, M., \& McCaughtry, N. (2001). Changes in basic tactics and motor skills in an invasion type game after a 12-lesson unit of instruction. Journal of Teaching Physical Education, 20, 352-369.

Oslin, J. L., Mitchell, S. A., \& Griffin, L. L. (1998). The game performance assessment instrument (GPAI): Development and preliminary validation. Journal of Teaching Physical Education, 17, 231-243.

Philipp, J. A., \& Wilkerson, J. D. (1990). Teaching team sports: A coeducational approach. Champaign, IL: Human Kinetics.

Rink, J. E. (2002). Teaching physical education for learning. $\left(4^{\text {th }}\right.$ Ed). New York: McGraw Hill.

Rink, J. E., French, K. E., \& Graham, C. (1996). Implications for practice and research. Journal of Teaching Physical Education, 15, 490-502.

Rovegno, I., Nevett, M., \& Babiarz, M. (2001). Invasion-game tactics in $4^{\text {th }}$ Grade: Introduction and theoretical 
perspective. Journal of Teaching Physical Education, 20, 341-351.

Shepherd, J. (2007). Sports Training: The Complete Guide. Buffalo, New York: Firefly Books Ltd.

Siedentop, D. (2001). Introduction to physical education, fitness, and sport $\left(4^{\text {th }} E d\right)$. Los Angeles, CA: Mayfield Publishing Company.

Thompson, P. J. (2000). Advanced Coaching Theory Level III. International Amateur Athletic Federation. Monaca Cedex.

Thompson, P. J. (1991). Introduction to coaching theory. International Amateur Athletic Federation. Monaca Cedex.

Turner, A. (1996). Teaching for understanding: Myth or reality?. Journal of Physical Education, Recreation and Dance, 67(4), 46-48.

Turner, A., \& Martinek, T. J. (1999). An investigation into teaching games for understanding: Effects on skill, knowledge, and play. Research Quarterly for Exercise and Sport, 70, 3-21.
Wassmer, D. J., \& Mookerjee, S. A. (2002). Descriptive Profile of Elie U.S. Women's Collegiate Field Hockey Players. Journal of Sports Medicine and Physical Fitness, 42(2), 165-171.

Werner, P., Thorpe, R., \& Bunker, D. (1996). Teaching games for understanding: Evolution of a model. Journal of Health, Physical Education, Recreation \& Dance, 67(1), 28-33.

Wilsmore, G., \& Curtis, O. (1992). Sport specific assessment of talented male and female junior hockey players. Sports Coach, April-June 15 (4): 33-37.

Wilmore, J. H., \& Costill, D. L. (1994). Physiology of sport and exercise. Champaign, IL: Human Kinetics.

Wrisberg, C. A. (1993), in Singer R., N., Murphy, M. \& Tennant, L. K. (1993). Handbook of research on sport psychology: A project of the international society of sport psychology. New York: Macmillan Publishing Company. 